\title{
PRELIMINARY EVALUATION OF LOCAL SITE CONDITON IN YOGYAKARTA BASIN
}

\author{
Tun Naing ${ }^{1}$, Subagyo Pramumijoyo*1, and Hiroshi Kawase ${ }^{2}$ \\ ${ }^{1}$ Department of Geological Engineering, Gadjah Mada University, Yogyakarta, Indonesia \\ ${ }^{2}$ Department of Architecture and Urban Design, Faculty of Human-Environment Studies, Kyushu University
}

\begin{abstract}
The Yogyakarta Basin can be defined as NE - SW elongated depression zone of $20 \mathrm{~km}$ in width and $45 \mathrm{~km}$ in length, trending from Yogyakarta City in north to the Indian Ocean in south. The local geologic and soil conditions have a great influence on the intensity of ground motion and earthquake damage. Local site effects play an important role in earthquake-resistant design and must be accounted for on a case by case basis. Local site conditions can profoundly influence all of the important characteristics such as amplitude (peak acceleration, velocity and displacement), frequency content and duration of strong ground motion. The extent of their influence depends on the geometry and material properties of subsurface materials. Therefore, subsurface investigation was carried out through nine boreholes throughout the basin. Based on drill-logs, collected samples and laboratory test results, the subsurface soil profiles of nine areas in the basin are simplified for future strong ground motion simulation. Five subsurface layers in Tampuran, Krajan areas and six subsurface soil layers in Watu, Jl. Parangtritis, Wijirejo areas and seven layers in Jl. Parangtritis, Karang Semut, Bambang Lipuro areas and eight layers in Pranti area, have been simplified and the geotechnical properties of each layer have been evaluated as well.
\end{abstract}

Keywords: Basin, Yogyakarta, depression, ground motion, earthquake.

${ }^{*}$ Corresponding author: S. PRAMUMIJOYO, Department of Geological Engineering, Faculty of Engineering, Gadjah Mada University, Jl. Grafika 2 Yogyakarta, 55281, Indonesia. E-mail: bagyo@ugm.ac.id

\section{Introduction}

The local geologic and soil conditions have a great influence on the intensity of ground motion and earthquake damage. Local site effects play an important role in earthquake-resistant design and must be accounted for on a case by case basis. Local site conditions can profoundly influence all of the important characteristics such as amplitude (peak acceleration, velocity and displacement), frequency content and duration of strong ground motion. The extent of their influence depends on the geometry and material properties of subsurface materials.

Therefore, the analysis of site amplification characteristics and evaluation of amplification factor in Yogyakarta Basin is primarily in need to understand the expected strong ground motion during the future earthquakes and to minimize the unexpected losses and damages in future. Moreover, Yogyakarta and other populated cities are located in this basin and so the evaluation of effects of basin geometry on strong ground motion is of great importance either.

\section{Nature of Yogyakarta basin}

The Yogyakarta Basin can be defined as NE-SW elongated depression zone of $20 \mathrm{~km}$ in width and $45 \mathrm{~km}$ in length from the Yogyakarta City to the Indian Ocean as shown in Figure 1. The basin was initiated by extrusions of two major volcanic centers; Kulon Progo Mountain and Southern Mountain, during Cenozoic and was formed as a volcano-tectonic depression 
since the Oligo-Miocene or earlier (Lucus et al., 2007). The regional gravity data suggest that the Yogyakarta Basin can be divided into several zones (Lucus et al., 2007). The first zone is in north of Yogyakarta City with the lowest gravity anomaly and is spatially associated with active Merapi volcano. Second is the moderate gravity anomaly region locating at the south and east of Yogyakarta City. The third is the high gravity anomaly locating as two separate clusters to the west and southeast of Yogyakarta City.

According to gravity data, it is important to note that the famous Opak Fault is not actually located at the eastern margin of the Yogyakarta Basin and the direction of Opak Fault which is aligned with the current topography is not aligned with the gravity trend.

\section{General geology}

Volcanic rocks and their derivatives dominate the studied Yogyakarta Basin. The geology of Yogyakarta Basin is shown in Figure 2. The extensive deposits of alluvium derived from $\mathrm{Gu}$ nung Merapi ejector mainly occur in this basin. In the eastern part, Miocene limestone is abundantly outcropped throughout the Wonosari and Gunung Sewu which are parts of Kabupaten Kidul. In Gunung Sewu, the typical karst topography which is developed under humid tropical climate can be observed well.

The rocks and sediments in this basin range in age from the Eocene to the Holocene. Throughout this period, continuous orogenic instability had resulted in significant faulting and volcanism which effected markly upon the geomorphic and geologic evolution of the basin.

\section{Yogyakarta Basin Quaternary Succession}

The quaternary succession is dominated by volcanic activities, largely attributable to Gunung Merapi. Other important deposits such as littoral clay deposits in the vicinity of Wates, minor valley and terrace alluvia in the main river valleys, deflation materials on limestone and sand dunes adjacent to the coast have also been encountered (MacDonald M. et al., 1984).
Old Merapi Volcanics Around the upper cone of Gunung Merapi, strongly fractured basalt and andesite lavas with indurated breccias occur and are deposits of Upper Pleistocene Merapi volcanism. The buried extension of these deposits does not extend far south as a deep bore hole in Yogyakarta has penetrated through the Post-Pleistocene deposits directly into the Tertiary strata.

Young Merapi Volcanics The materials ejected from Merapi since the Major explosion which is thought to have taken place in 1006 AD are considered as the Younger Merapi Volcanics. These predominantly consist of andesite lavas and tuffs. They outcrop in the vicinity of cone of Merapi.

Sleman Formation The Sleman formation has been designated as the lower part of a major volcaniclastic unit which was formerly included in the Younger Merapi Volcanics (Van Bemmelen, 1949). The formation extends from upper Merapi slope to the south of Bantul. In the north, on the Merapi Upper Slope, it consists of sand and gravels with interspersed boulders, all derived from volcanic ejector. From Yogyakarta to south, the formation is overlain by Yogyakarta Formation and so the full thickness of Sleman Formation can be identified in the bore holes. This formation is thought to be Upper Pleistocene to Holocene in age and the thickness is variable.

Yogyakarta Formation It forms the surface outcrop throughout the lowland area of Yogyakarta Basin from Merapi Middle Slope to the coast. The formation consists of an interbedded sequence of sand, gravels, silts and clay. The amount of clay increases southwards. However, the layers of coarse materials have been encountered throughout the basin. Thickness of this formation is variable and up to 45 $\mathrm{m}$ in some places. This formation lies unconformable upon the Sleman Formation.

Wates Formation This formation occurs in the lower Kali Serang forming a lowland triangle between Seragater, Pengasih, and Plempukan. 


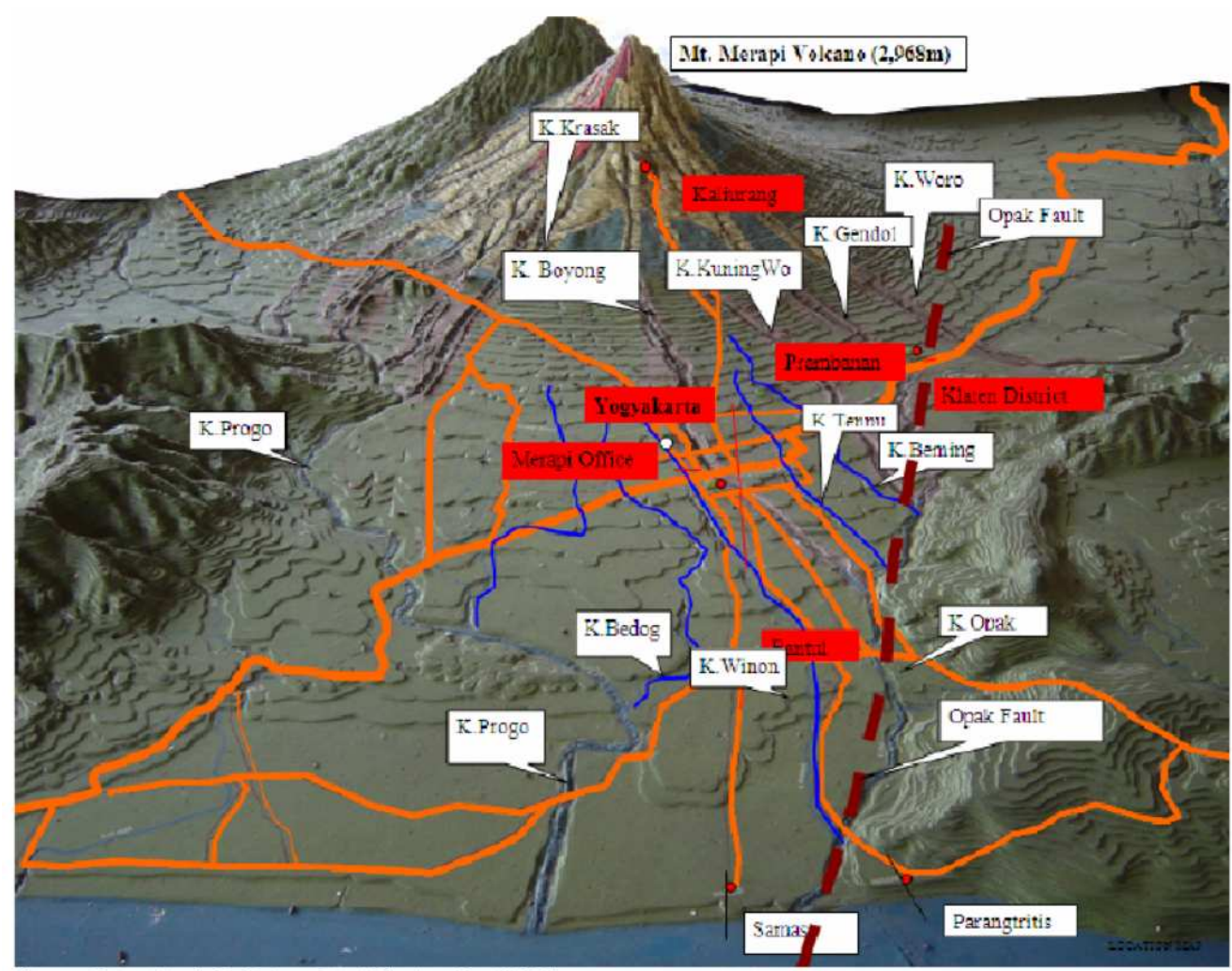

Sourre: Japan Bank for International Cooperation (JBIC)

Figure 1: Location of Yogyakarta basin

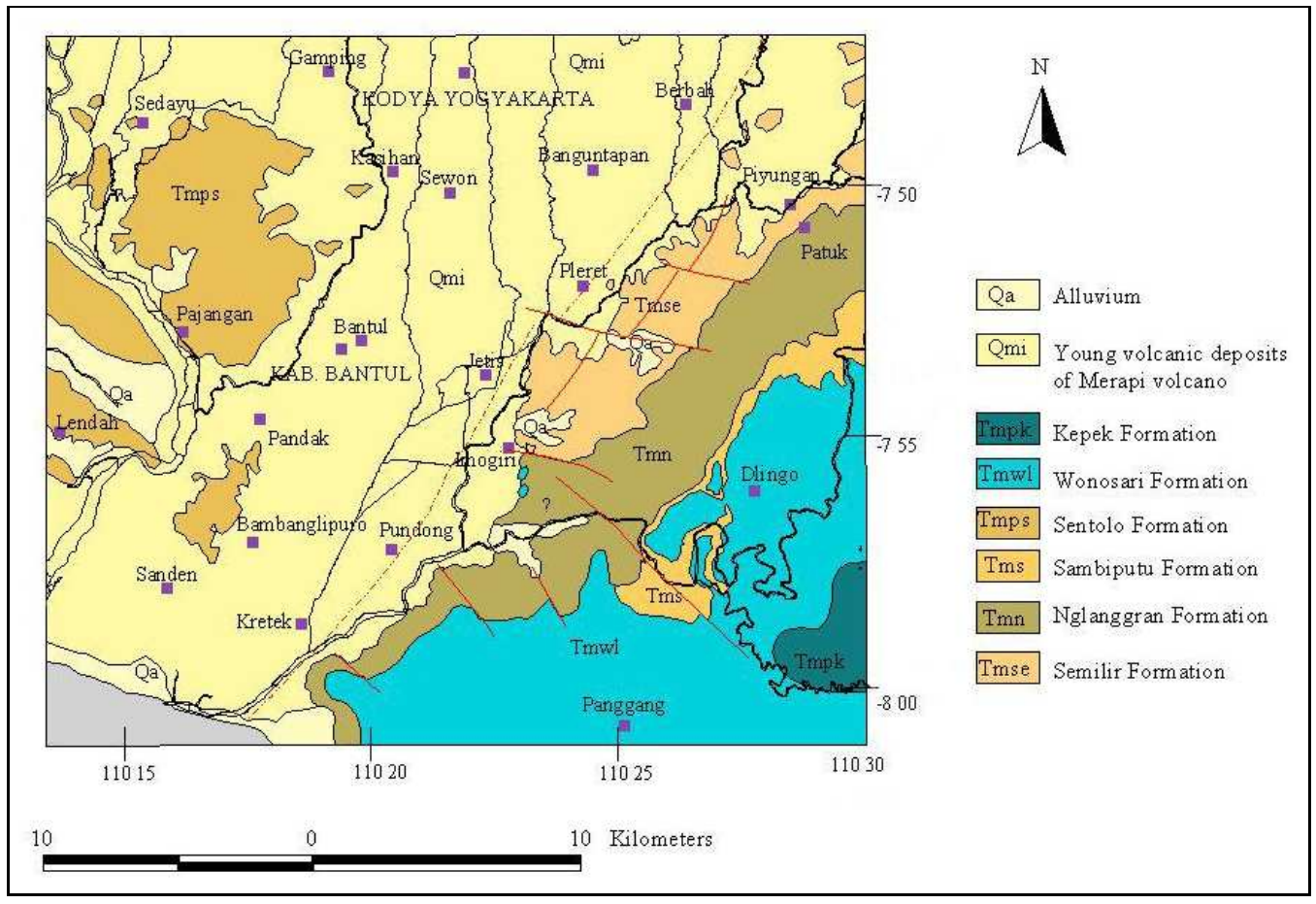

Figure 2: General geological map of Yogyakarta basin 
It has also been observed in south of Bantul, on the coastal alluvial plain. This formation includes the littoral deposits of silts and clay derived from weathering products of the Sentolo Hills and the West Progo Mountains. Above the littoral sequence, the fluvial deposits which mainly contain clays with sand lens in the upper section have been occurred.

On the coastal plain south of Bantul, littoral sands and gravels are allocated to the Wates Formation. These deposits are believed to be reworked materials from the Yogyakarta Formation. The age of this formation is Middle Holocene and the thickness is variable, $20 \mathrm{~m}$ to $30 \mathrm{~m}$.

Coastal Sand Dunes Fine to coarse grained sands are mainly present as dunes along the coast from Kali Bogowonto to the Kali Opak. The dimensions of sand dunes are up to $1.5 \mathrm{~km}$ in width and up to about $40 \mathrm{~m}$ in thickness. They are overlying on Wates and Yogyakarta Formations. They may be Upper Holocene in age.

\section{Geotechnical investigation}

The detailed drilling program had been carried out for subsurface investigation in Yogyakarta Basin. There are nine boreholes throughout the basin especially in Bantul area to evaluate the geotechnical properties of subsurface soil layers as shown in Figure 3. The boreholes were generally drilled up to the bedrock. The depths are varying from $20 \mathrm{~m}$ to $50 \mathrm{~m}$.

The borehole No. 1 is located in Watu, Pundone, Bantul area and drilled up to $35 \mathrm{~m}$. The groundwater table was at surface. Medium to gravelly coarse sand are mainly observed in upper $1 \mathrm{~m}$ and silt to fine sand are dominated from $1 \mathrm{~m}$ to $20 \mathrm{~m}$ depth. This portion will be a major zone for the consideration of ground motion and amplification. This zone is underlain by 1 $\mathrm{m}$ thick clay layer. The bedrock, breccia, is encountered starting from $22 \mathrm{~m}$ to $30 \mathrm{~m}$. Blackish brown, fine-grained, hard sandstone is observed after $30 \mathrm{~m}$ dept.

Based on drilled log, collected samples and laboratory test results, 6 subsurface layers have been classified in Watu area: (1) Grayish brown to brown sand mixed with silt, (2) Light brown to dark gray fine sand mixed with clay silt, medium to high plasticity, (3) Light brown to brown silty fine sand, medium plasticity, (4) Blackish gray clay, high plasticity, (5) Greenish brown, reddish brown, compact breccia, and (6) Blackish brown, fine-grained sandstone. The geotechnical properties of each layer have been described in the Table 1.

The borehole No. 2 is located in Tempuran, near Opak River. It was drilled just up to $26 \mathrm{~m}$ since bedrock had been encountered starting at $13 \mathrm{~m}$. The groundwater table in this area is very shallow and observed at $2.5 \mathrm{~m}$ depth. Fine to medium uniform sand had been observed up to $12 \mathrm{~m}$. This zone is very loose $(\mathrm{N}<20)$ and so the high amplification can be expected in this zone. This zone is underlain by $1 \mathrm{~m}$ thick clay layer. The bedrock, breccia, was encountered starting from $13 \mathrm{~m}$.

Based on drilling log, collected samples and laboratory test results, the soil profile at Tempuran area can be differentiated into 5 layers: (1) Brown, fine clayey sand with few andesite gravels, (2) Brownish gray to blackish gray medium to coarse sand mixed with silts, (3) Brownish gray to blackish gray fine clayey sand, (4) Greenish gray, slight compact clay of high plasticity, and (5) Yellowish brown, grayish brown, with andesite and sandstone fragments, compact and hard. The geotechnical parameters of each layer are described in the Table 2.

The borehole No. 3 is in Pranti, Pundong, Bantul and drilled up to $40 \mathrm{~m}$ depth. The groundwater table was encountered at the depth of $14.6 \mathrm{~m}$. It is an area of thick sand deposit. Bedrock is encountered after $30 \mathrm{~m}$ depth and which is overlain by sand deposit with different layers. This is an area of thick unconsolidated sediment, and so high amplification and strong ground motion during an earthquake can be expected in this area.

The subsurface soil profile of this area has be divided into 8 layers based on drill log, collected samples: (1) Black clay with high plasticity, (2) Fine sands with silts with medium plasticity, (3) Dark brown to black clay with high plasticity, (4) Silt with high plasticity, (5) Brown 


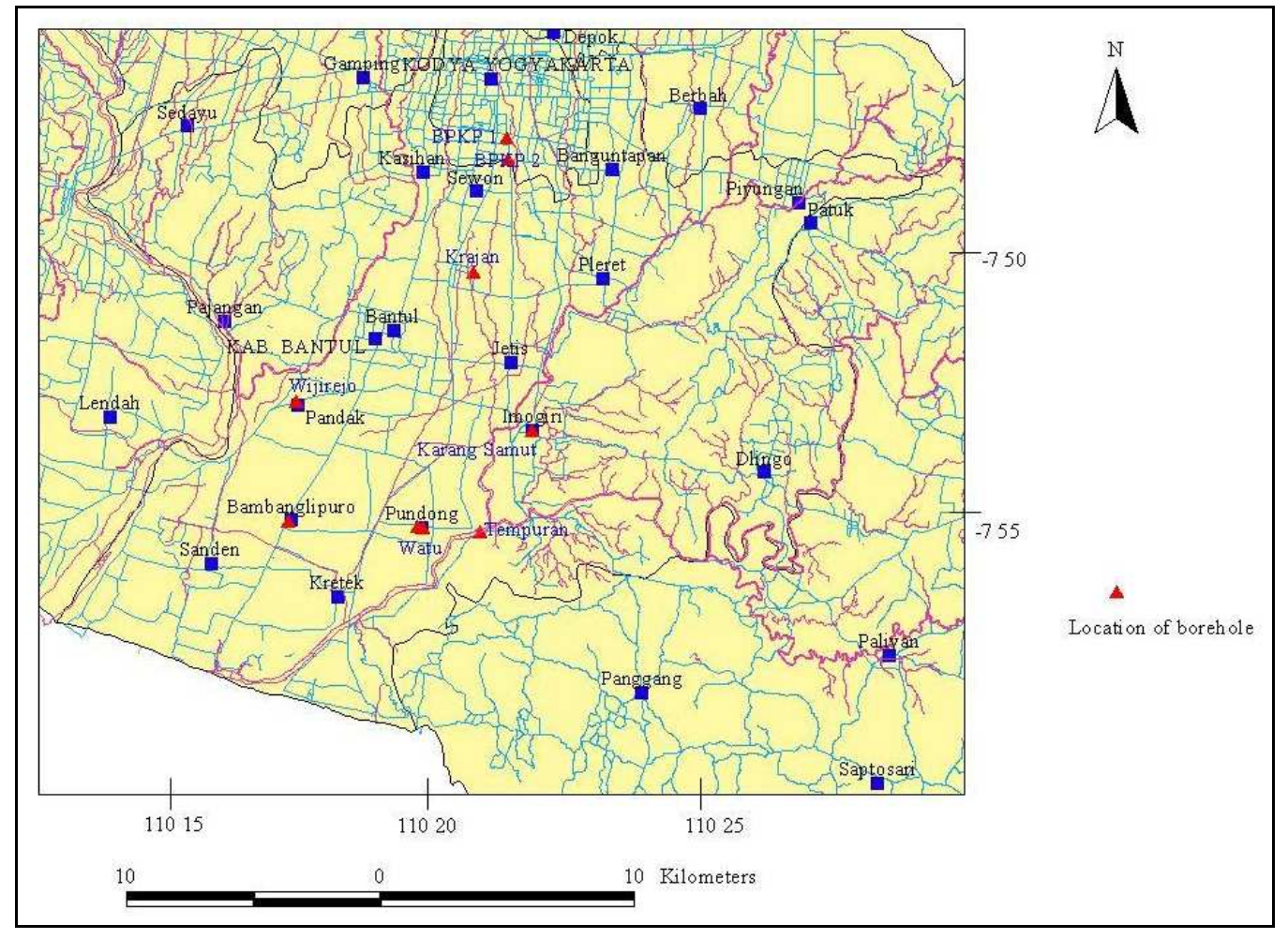

Figure 3: Location of Boreholes in Yogyakarta Basin

fine sands mixed with silts and clay, (6) Brownish gray sand mixed with clays and gravels, (7) Black clay with high plasticity, and (8) Greenish brown, compacted breccia. The laboratory test data and the geotechnical properties of each layer are described in the Table 3.

The borehole No. 4 is located on Jl. Parangtritis, Yogyakarta. It was drilled up to $30 \mathrm{~m}$ but did not reach bedrock. The upper $7 \mathrm{~m}$ is mainly composed of medium to coarse sand. Fine sand becomes more dominant after $7 \mathrm{~m}$ depth with two clay layers at $21 \mathrm{~m}$ depth and $23 \mathrm{~m}$ depth. The groundwater table was observed at $5.5 \mathrm{~m}$ depth. The subsurface soil profile of this area can be classified 6 layers: (1) Brownish to blackish gray uniform, medium grain sand with fines and gravels, (2) Fine sand with silts, medium plasticity, (3) Brownish gray, uniform, medium grained sand with gravels, (4) Brown fine sand mixed with silt, clay, medium plasticity, (5) Grayish clay, high plasticity, and (6) Sandstone, underlain by gravelly fine sand. The available geotechnical properties for each layer are summarized in the Table 4.

The borehole No. 5 is also located in $\mathrm{Jl}$.
Parangtritis, Yogyakarta. It was drilled only up to $20 \mathrm{~m}$ depth, not reached to bedrock. The groundwater table was found at $5.7 \mathrm{~m}$. This area is mainly composed of sandy deposit which is mixed with silt and gravel. According to SPT results, this is an area of medium dense sediments. Based on drill log and collected core samples, this area is divided into seven layers: (1) Grayish brown sand mixed with fines with medium plasticity, (2) Medium to coarse, gray sand mixed with andesite gravels, (3) Light brown to grayish brown fine sand mixed with silt, with medium plasticity, (4) Grayish brown, fine to medium grain sandstone, (5) Brownish gray to gray medium grain, uniform sand with few fines, (6) Silt with medium plasticity, and (7) Gray medium grain, uniform sand. Some geotechnical properties of each layer are summarized in the Table 5.

The borehole No. 6 is in Karang Semut, Imogiri, Bantul. It was drilled up to only $20 \mathrm{~m}$ depth as bedrock, sandstones, are encountered at 14 $\mathrm{m}$. The groundwater table was observed at 8.5 $\mathrm{m}$ depth. The upper $4 \mathrm{~m}$ is mainly composed of fine to medium sand and two sandstone lay- 
ers are observed at depth $4.5 \mathrm{~m}$ and $7.5 \mathrm{~m}$. The clay layer, $2 \mathrm{~m}$ thick, is found at $12 \mathrm{~m}$ depth and which is overlying on sandstone bedrock.

Based on drill log and collected samples, the soil profile of this area can be differentiated into seven layers: (1) Brown to brownish gray sand, mixed with fines and gravels, (2) Brown, fine grained sandstone, (3) Brown sand mixed with silts, medium plasticity, (4) Brown, fine grained sandstone, (5) Brown to blackish gray sand, mixed with silts and gravel, medium plasticity, (6) Black clay with high plasticity, and (7) Brown, fine grained sandstone. The geotechnical properties of each layer are described in the Table 6.

The borehole No. 7 is located in Krajan, Poncosari, Bantul. It was drilled up to $47 \mathrm{~m}$ depth. This area is mainly dominated by thick sandy deposit of various grain sizes. The bedrock is encountered at $30 \mathrm{~m}$ depth and the groundwater table in this area is very shallow and found at $1.70 \mathrm{~m}$ depth. Based on drill log and collected samples, the subsurface soil profile in this area can be classified into 5 layers: (1) Brownish gray, medium sand with some fines, (2) Blackish gray, coarse sand with no fines, (3) Brownish gray to gray, coarse sand mixed with gravels and fines, (4) Brownish gray to gray, fine to medium sand mixed with silts, and (5) Brown, fine grained sandstone. Some geotechnical properties of each layer are described in the Table 7.

The borehole No. 8 is located in Bambang Lipuro, Bantul and drilled up to $50 \mathrm{~m}$ depth. The groundwater table is shallow and observed at $2 \mathrm{~m}$ depth. This is an area of sand, silts and clay deposit up to $26 \mathrm{~m}$. Breccia is observed at $26 \mathrm{~m}$ depth and up to $35 \mathrm{~m}$. After $35 \mathrm{~m}$, sand layer, breccia and fine grained sandstone layers are alternated up to $45 \mathrm{~m}$ depth. Fine grained sandstone layer is encountered from 45 $\mathrm{m}$ to $50 \mathrm{~m}$, end of borehole. The subsurface profile of this area has been classified into 8 layers: (1) Brownish gray to gray, fine to medium sand, (2) Greenish gray, fine sand mixed with silts, medium plasticity, (3) Blackish brown to gray sand mixed with fines, (4) Brown clay of high plasticity, (5) Greenish gray to blackish gray sand mixed with silts and gravels, (6)
Black clay of high plasticity, and (7) Breccia and sandstones intercalated with sand layers. Some geotechnical properties of each subsurface layer of this area are described in the Table 8.

The borehole No. 9 is in Wijirejo, Pandak, Bantul area. It was drilled up to $47 \mathrm{~m}$ depth. The bedrock is encountered at $19 \mathrm{~m}$ depth and overlain by moderately dense sandy deposit of different grain sizes. The groundwater table is very shallow and observed at $2 \mathrm{~m}$ depth. The subsurface profile of this area is divided into 6 layers based on drill log and collected samples: (1) Grayish brown to gray sand mixed with clays, (2) Gray medium to coarse sand, (3) Greenish brown, high plasticity clay, (4) Gray medium grained sand mixed with gravels, (5) Black, high plasticity clay, and (6) Brown to blackish brown fine-grained sandstones, intercalated with clay and mudstones. Some geotechnical properties of each layer are summarized in the Table 9.

\section{Discussion}

In this study, the subsurface soil profiles and soil types are determined according to United State Soil Classification (USCS) system, based on grained size analysis, Atterberg's Limits Test and drill logs. The shear strength parameters are obtained from direct shear test and tri-axial test. The water content, void ratio and specific gravity for each layer also determined. These subsurface profiles and properties are fundamental input parameters for ground response analyses.

Loose to medium dense sand, silt and clay sediments are mainly dominant in most areas and the shallow groundwater table is observed in most of areas. Therefore, the amplification of seismic waves can be expected into a certain level. The clayey and silty sand layers are encountered up to $30 \mathrm{~m}$ depth in Watu, Tampuran and Pranti areas. The high amplification and strong ground motion can occur in these areas. Well graded and poorly graded sand layers and silty sand layers dominate In J1. Parantritis and this area can be regarded as a dangerous area of earthquake related settlement.

In Karang Semut area, two hard sandstone 
Table 1: Geotechnical properties of each subsurface layer at Watu area

\begin{tabular}{|c|c|c|c|c|c|c|}
\hline Layer & $\begin{array}{l}\text { Thickness } \\
\text { (m) }\end{array}$ & $\begin{array}{l}\text { Soil \& rock } \\
\text { Type }\end{array}$ & $\begin{array}{l}\text { Specific } \\
\text { Gravity }\end{array}$ & $\begin{array}{l}\text { Plasticity } \\
\text { Index (PI) }\end{array}$ & $\begin{array}{c}\text { Strength } \\
\text { Direct } \\
\phi\end{array}$ & $\begin{array}{l}\text { Parameters } \\
\text { Shear } \\
\mathrm{c}\left(\mathrm{kg} / \mathrm{cm}^{2}\right)\end{array}$ \\
\hline 1 & 4 & SM & 2.85 & -- & 37.87 & 0.12 \\
\hline 2 & 7.5 & $\mathrm{SC}$ & 2.66 & 42.78 & 39.24 & 0.13 \\
\hline 3 & 9 & ML & 2.69 & 59.24 & 38.56 & 0.14 \\
\hline 4 & 1 & $\mathrm{CH}$ & 2.4 & 49.89 & -- & -- \\
\hline 5 & 8.5 & Breccia & 2.68 & 90.5 & -- & -- \\
\hline 6 & $>5$ & Sandston & -- & -- & -- & -- \\
\hline
\end{tabular}

Table 2: Geotechnical properties of each subsurface layer at Tampuran area

\begin{tabular}{|c|c|c|c|c|c|c|}
\hline Layer & $\begin{array}{c}\text { Thickness } \\
\text { (m) }\end{array}$ & $\begin{array}{c}\text { Soil \& rock } \\
\text { Type }\end{array}$ & $\begin{array}{l}\text { Specific } \\
\text { Gravity }\end{array}$ & $\begin{array}{l}\text { Plasticity } \\
\text { Index (PI) }\end{array}$ & $\begin{array}{l}\text { Strength } \\
\text { Direct } \\
\phi\end{array}$ & $\begin{array}{l}\text { Parameters } \\
\text { Shear } \\
\mathrm{c}\left(\mathrm{kg} / \mathrm{cm}^{2}\right)\end{array}$ \\
\hline 1 & 1.7 & $\mathrm{SC}$ & 2.73 & 17.91 & -- & - \\
\hline 2 & 6.3 & SM & 2.76 & -- & 38.95 & 0.10 \\
\hline 3 & 4 & $\mathrm{SC}$ & 2.84 & -- & 38.35 & 0.11 \\
\hline 4 & 1 & $\mathrm{CH}$ & -- & -- & 37.56 & 0.13 \\
\hline 5 & 15 & Breccia & -- & -- & -- & -- \\
\hline
\end{tabular}

Table 3: Geotechnical properties of each subsurface layer at Pranti area

\begin{tabular}{|c|c|c|c|c|c|c|}
\hline Layer & $\begin{array}{l}\text { Thickness } \\
\text { (m) }\end{array}$ & $\begin{array}{c}\text { Soil \& rock } \\
\text { Type }\end{array}$ & $\begin{array}{l}\text { Specific } \\
\text { Gravity }\end{array}$ & $\begin{array}{l}\text { Plasticity } \\
\text { Index (PI) }\end{array}$ & $\begin{array}{l}\text { Strength } \\
\text { Direct } \\
\phi\end{array}$ & $\begin{array}{l}\text { Parameters } \\
\text { Shear } \\
\mathrm{c}\left(\mathrm{kg} / \mathrm{cm}^{2}\right)\end{array}$ \\
\hline 1 & 4.2 & $\mathrm{CH}$ & 2.49 & 24.08 & -- & -- \\
\hline 2 & 4.5 & SM & 2.82 & -- & 38.87 & 0.13 \\
\hline 3 & 2 & $\mathrm{CH}$ & -- & -- & -- & -- \\
\hline 4 & 4 & MH & 2.58 & 32.42 & 38.11 & 0.11 \\
\hline 5 & 5.5 & SM & 2.77 & -- & 39.69 & 0.11 \\
\hline 6 & 8 & $\mathrm{SC}$ & 2.69 & -- & 37.33 & 0.05 \\
\hline 7 & 1.5 & $\mathrm{CH}$ & -- & -- & -- & -- \\
\hline 8 & 9.5 & Breccia & -- & -- & -- & -- \\
\hline
\end{tabular}

Table 4: Geotechnical properties of each subsurface layer at BPKP 1, Jl. Parangtritis area, Yogyakarta

\begin{tabular}{|c|c|c|c|c|c|c|}
\hline Layer & $\begin{array}{l}\text { Thickness } \\
\text { (m) }\end{array}$ & $\begin{array}{l}\text { Soil \& rock } \\
\text { Type }\end{array}$ & $\begin{array}{l}\text { Specific } \\
\text { Gravity }\end{array}$ & $\begin{array}{l}\text { Plasticity } \\
\text { Index (PI) }\end{array}$ & $\begin{array}{c}\text { Strength } \\
\text { Direct } \\
\phi \\
\end{array}$ & $\begin{array}{l}\text { Parameters } \\
\text { Shear } \\
\mathrm{c}\left(\mathrm{kg} / \mathrm{cm}^{2}\right)\end{array}$ \\
\hline 1 & 5.7 & SP & 2.65 & 20.97 & -- & -- \\
\hline 2 & 5.3 & SM & 2.57 & 12.18 & -- & -- \\
\hline 3 & 1.5 & SP & -- & -- & -- & -- \\
\hline 4 & 10.5 & SM & 2.7 & 7.73 & 37.57 & 0.11 \\
\hline 5 & 2.5 & $\mathrm{CH}$ & 2.36 & 50.38 & -- & -- \\
\hline 6 & 4.5 & Sandstone & -- & -- & -- & -- \\
\hline
\end{tabular}


NAING et al.

Table 5: Geotechnical properties of each subsurface layer at BPKP 2, Jl. Parangtritis area, Yogyakarta

\begin{tabular}{|c|c|c|c|c|c|c|}
\hline Layer & $\begin{array}{l}\text { Thickness } \\
\text { (m) }\end{array}$ & $\begin{array}{c}\text { Soil \& rock } \\
\text { Type }\end{array}$ & $\begin{array}{l}\text { Specific } \\
\text { Gravity }\end{array}$ & $\begin{array}{l}\text { Plasticity } \\
\text { Index (PI) }\end{array}$ & $\begin{array}{l}\text { Strength } \\
\text { Direct } \\
\phi\end{array}$ & $\begin{array}{l}\text { Parameters } \\
\text { Shear } \\
\mathrm{c}\left(\mathrm{kg} / \mathrm{cm}^{2}\right)\end{array}$ \\
\hline 1 & 4 & SM & 2.58 & -- & 38.19 & 0.11 \\
\hline 2 & 3 & SW & 2.77 & -- & 37.56 & 0.11 \\
\hline 3 & 2 & SM & 2.73 & -- & 38.05 & 0.08 \\
\hline 4 & 1.5 & Sandstone & -- & -- & -- & -- \\
\hline 5 & 4.5 & $\mathrm{SP}$ & 2.59 & 8.22 & -- & -- \\
\hline 6 & 2 & ML & 2.56 & 6.20 & -- & -- \\
\hline 7 & 3 & SP & 2.67 & -- & 37.62 & 0.15 \\
\hline
\end{tabular}

Table 6: Geotechnical properties of each subsurface layer at Karang Semut, Imogiri, Bantul

\begin{tabular}{|c|c|c|c|c|c|c|}
\hline Layer & $\begin{array}{c}\text { Thickness } \\
\text { (m) }\end{array}$ & $\begin{array}{c}\text { Soil \& rock } \\
\text { Type }\end{array}$ & $\begin{array}{l}\text { Specific } \\
\text { Gravity }\end{array}$ & $\begin{array}{l}\text { Plasticity } \\
\text { Index (PI) }\end{array}$ & $\begin{array}{l}\text { Strength } \\
\text { Direct } \\
\phi\end{array}$ & $\begin{array}{l}\text { Parameters } \\
\text { Shear } \\
\mathrm{c}\left(\mathrm{kg} / \mathrm{cm}^{2}\right)\end{array}$ \\
\hline 1 & 4.5 & SC & 2.67 & -- & 39.25 & 0.11 \\
\hline 2 & 1.5 & Sandstone & -- & -- & -- & -- \\
\hline 3 & 1 & SM & 2.67 & -- & 38.88 & 0.10 \\
\hline 4 & 1 & Sandstone & -- & -- & -- & -- \\
\hline 5 & 3.5 & SP & 2.77 & -- & 38.34 & 0.11 \\
\hline 6 & 2 & $\mathrm{CH}$ & -- & -- & -- & -- \\
\hline 7 & 6 & Sandstone & -- & -- & -- & -- \\
\hline
\end{tabular}

Table 7: Geotechnical properties of each subsurface layer at Krajan, Bantul

\begin{tabular}{|c|c|c|c|c|c|c|c|}
\hline Layer & $\begin{array}{c}\text { Thickness } \\
(\mathrm{m})\end{array}$ & $\begin{array}{c}\text { Soil \& rock } \\
\text { Type }\end{array}$ & $\begin{array}{c}\text { Specific } \\
\text { Gravity }\end{array}$ & $\begin{array}{c}\text { Plasticity } \\
\text { Index (PI) }\end{array}$ & $\begin{array}{c}\text { Void } \\
\text { Ratio } \\
(\mathrm{e})\end{array}$ & $\begin{array}{c}\text { Strength } \\
\text { Direct } \\
\phi\end{array}$ & $\begin{array}{l}\text { Parameters } \\
\text { Shear } \\
\mathrm{c}\left(\mathrm{kg} / \mathrm{m}^{2}\right)\end{array}$ \\
\hline 1 & 9 & SP & 2.89 & -- & 1.71 & 38.69 & 0.05 \\
2 & 2.5 & SM & 2.79 & -- & 1.62 & 36.63 & 0.09 \\
3 & 5.5 & SP & 2.79 & -- & 1.62 & 33.06 & 0.15 \\
4 & 10 & SM & 2.81 & -- & 1.64 & 37.11 & 0.10 \\
5 & 19 & Sandstone & 2.70 & -- & 1.53 & 37.01 & 1.36 \\
\hline
\end{tabular}

Table 8: Geotechnical properties of each subsurface layer at Bambang Lipuro, Bantul

\begin{tabular}{|c|c|c|c|c|c|c|c|}
\hline Layer & $\begin{array}{c}\text { Thickness } \\
(\mathrm{m})\end{array}$ & $\begin{array}{c}\text { Soil \& rock } \\
\text { Type }\end{array}$ & $\begin{array}{c}\text { Specific } \\
\text { Gravity }\end{array}$ & $\begin{array}{c}\text { Plasticity } \\
\text { Index }(\mathrm{PI})\end{array}$ & $\begin{array}{c}\text { Void } \\
\text { Ratio } \\
(\mathrm{e})\end{array}$ & $\begin{array}{c}\text { Strength } \\
\text { Direct } \\
\phi\end{array}$ & $\begin{array}{l}\text { Parameters } \\
\text { Shear } \\
\mathrm{c}\left(\mathrm{kg} / \mathrm{m}^{2}\right)\end{array}$ \\
\hline 1 & 4 & $\mathrm{SC}$ & 2.67 & -- & 1.51 & -- & - \\
2 & 2 & $\mathrm{SM}$ & 2.61 & 25.25 & 1.45 & 37.43 & 0.08 \\
3 & 10 & $\mathrm{SP}$ & 2.63 & 12.54 & 1.47 & 35.78 & 0.15 \\
4 & 2 & $\mathrm{CH}$ & 2.51 & 54.97 & 1.36 & -- & -- \\
5 & 6.5 & $\mathrm{SP}$ & 2.60 & -- & 1.45 & -- & - \\
6 & 1.5 & $\mathrm{CH}$ & 2.51 & -- & 1.35 & -- & - \\
7 & 24 & Sandstone & -- & -- & -- & -- & - \\
\hline
\end{tabular}


Table 9: Geotechnical properties of each subsurface layer at Wijirejo, Pandak, Bantul

\begin{tabular}{|c|c|c|c|c|c|c|c|}
\hline Layer & $\begin{array}{c}\text { Thickness } \\
(\mathrm{m})\end{array}$ & $\begin{array}{c}\text { Soil \& rock } \\
\text { Type }\end{array}$ & $\begin{array}{c}\text { Specific } \\
\text { Gravity }\end{array}$ & $\begin{array}{c}\text { Plasticity } \\
\text { Index (PI) }\end{array}$ & $\begin{array}{c}\text { Void } \\
\text { Ratio } \\
(\mathrm{e})\end{array}$ & $\begin{array}{c}\text { Strength } \\
\text { Direct } \\
\phi\end{array}$ & $\begin{array}{l}\text { Parameters } \\
\text { Shear } \\
\mathrm{c}\left(\mathrm{kg} / \mathrm{m}^{2}\right)\end{array}$ \\
\hline 1 & 8 & $\mathrm{SC}$ & 2.63 & 17.17 & 1.47 & 36.09 & 0.76 \\
2 & 7 & $\mathrm{SP}$ & 2.80 & -- & 1.63 & -- & -- \\
3 & 1 & HC & -- & -- & -- & -- & -- \\
4 & 1.2 & SP & -- & -- & -- & -- & - \\
5 & 1.8 & HC & 2.51 & 25.41 & 1.36 & 34.90 & 0.09 \\
6 & 26 & Bedrock & 2.75 & -- & 1.58 & -- & -- \\
\hline
\end{tabular}

layers are sandwiched between clayey and silty sand layers at $4.5 \mathrm{~m}$ and $7.5 \mathrm{~m}$ depths. The different impedance ratio will cause trapping all seismic waves in soil layers and more cycles of dynamic loading can be expected. Silty sand and poorly graded sand layers are mainly observed in Krajan area. This area can occur liquefaction problems during an earthquake due to sediment types and shallow groundwater table.

In Bambang Lipuro and Wijirejo areas, two high plasticity clay layers are encountered among sandy layers. The shallow groundwater table, at $2 \mathrm{~m}$ depth, and these clay layers can cause high pore-water pressure in sandy layers during an earthquake and strong motion and settlement problems can be expected. Moreover, the high plasticity clay layer is usually observed as base layer of all soil layers in all area. This clay layer is very weak $(\mathrm{N}<13)$ and will generate strong motion to the overlying soil layers.

The soil layers are underlain by hard sandstone or breccia layer at generally at $30 \mathrm{~m}$, in all studied areas. In such situation, the hard sandstone or breccia acts as a fixed end and any downward-traveling waves in soil layers will be completely reflected back towards the ground surface when they reach soil-rock boundary. Therefore, all seismic wave energy is trapped within the soil layers and strong ground motion can be occurred in the Yogyakarta Basin.

\section{Conclusions}

In this study, the site condition is evaluated mainly based on geotechnical evaluation in nine areas in Yogyakarta Basin through borehole logs, results from direct shear test, tri-axial test, Atterberg's Limits test, and determination of specific gravity, water content, degree of saturation, density and void ratio. As a result, the following facts are concluded.

1. The subsurface soil profiles and related geotechnical parameters have been evaluated in nine areas for determination strong ground motion and ground response analyses.

2. The shear strength parameters, standard penetration test results, void ratio and other basic geotechnical parameters have been determined for the estimation of shear wave velocity structures of the basin. Shear wave velocity structure is very fundamental in seismic response analysis.

3. Loose to medium dense sediments are dominant in most studied areas and which are underlain by hard sandstone or breccia layer generally at $30 \mathrm{~m}$ depth, as engineering bedrock.

However, there are some limitations in this study. The additional drilling program is required to create the basin model. More tri-axial test results are also needed to determine the initial shear stress and shear strength of soil layers.

\section{Acknowledgement}

Sincere gratitude is directed to Geological Engineering Department, UGM and Japan Inter- 
national Co-operation Agency (JICA) for their supports in every academic affair. The great debt of gratitude is to my advisor Dr. Subagyo Pramumijoyo for his guidance and suggestions. The acknowledgement is extended to Professor Dr. Hiroshi Kawase for his empowerment and advices.

\section{References}

Craig R. F. (1991) Soil Mechanics, CHAPMAN \& HALL, 2-6 Boundary Row, London SE1 8HN.
Das B. M. (1993) Principles of Soil Dynamics, PWS-KENT Publishing Company, Boston, Massachusetts.

Kramer, S.L. (1996) Geotechnical Earthquake Engineering, Prentice Hall, New Jersey.

Lucas, D. S. et al. (2007) Searching for the Active fault of Yogyakarta Earthquake 2006: current interpretation based on the reconstruction of Cenozoic Geo-history, Geological Engineering Department, UGM, Indonesia.

McDonald M. et al. (1984) Greater Yogyakarta Groundwater Resources Study, volume 3, Ministry of Public Work, Indonesia. 